\title{
Agronomic Performance of Sunflower Hybrids in the Mid-Northern Region of Mato Grosso, Brazil
}

\author{
Flávio Carlos Dalchiavon ${ }^{1}$, Welington Junior Cândido da Silva ${ }^{1}$, Rosivaldo Hiolanda (In memorian) ${ }^{1}$, \\ Felipe Rottoli Vicari ${ }^{1} \&$ Claudio Guilherme Portela de Carvalho ${ }^{2}$ \\ ${ }^{1}$ Department of Agronomy, Federal Institute of Education, Science and Technology of Mato Grosso/IFMT, \\ Campo Novo do Parecis, MT, Brazil \\ ${ }^{2}$ Researcher Embrapa Soja, Londrina, PR, Brazil \\ Correspondence: Flávio Carlos Dalchiavon, Department of Agronomy, Federal Institute of Education, Science \\ and Technology of Mato Grosso/IFMT, 78360-000, Campo Novo do Parecis, MT, Brazil. Tel: 55-65-99617-5059. \\ E-mail: flavio.dalchiavon@cnp.ifmt.edu.br
}

Received: March 23, 2020

doi:10.5539/jas.v12n6p182
Accepted: May 2, $2020 \quad$ Online Published: May 15, 2020

URL: https://doi.org/10.5539/jas.v12n6p182

\begin{abstract}
Helianthus annus L. belongs to the family Asteraceae, with a yearly cycle and high adaptability rate to different climate conditions. Its culture was boosted by the production of animal feed, oil extraction for humans or for biodiesel, ornamentation and bird feed. The agronomic performance of sunflower genotypes in the Mid-Northern region of the State of Mato Grosso, Brazil, was assessed. Data for the production and industrial sectors will be thus provided for the selection of genotypes with the best agronomic traits when cultivated in the region. Current study was performed at the Instituto Federal de Educação, Ciência e Tecnologia de Mato Grosso, on the Campus Campo Novo do Parecis MT Brazil, during 2018. Eight genotypes were evaluated in assays with randomized blocks and four replications. Evaluated traits comprised days for initial florescence, plant height, stalk diameter, green and dry mass, days for physiological maturity, mean diameter of the head, mass of head and achenes per head, both necessary to obtain achene:head ratio, mass of one thousand achenes, number of achenes per head and productivity of achenes of the oil. Genotypes with high grain yield tended towards greater size and cycle. Genotypes SYN 045, BRS 323 and MULTISSOL had good grain productivity plus good production of green and dry mass. The first two genotypes had an oil rate above $40 \%$, with good oil productivity.
\end{abstract}

Keywords: Helianthus annuиs L., oleaginous plant, productivity of achenes, variety adaptation

\section{Introduction}

The sunflower (Helianthus annus L.) belongs to the family Asteraceae, with a yearly cycle and high adaptability rate to different climate conditions. Its culture was boosted by the production of animal feed, oil extraction for humans or for biodiesel, ornamentation and bird feed (Porto, Carvalho, Pinto, M. F. Oliveira, \& A. C. B. Oliveira, 2008; Kösoğlu, Yumuk, Aydin, Evci, \& Uncuoğlu, 2017; Castro \& Leite, 2018).

Brazil has a mere $0.5 \%$ in grain production of sunflower worldwide. Cultivated area in Brazil for the 2017-2018 harvest reached 95.5 thousand hectares, with a production of 150.7 thousand tons of grains and mean productivity of $1,578 \mathrm{~kg} \mathrm{ha}^{-1}$. There was, however, an increase from 32.8 thousand ha to 47 thousand tons of grain when compared to the 2016-2017 harvest (CONAB, 2018). In the 2017-2018 harvest, the state of Mato Grosso, the greatest grain producer in Brazil, produced 101.1 thousand tons of grains in 60.5 thousand ha, with a mean productivity of $1,626 \mathrm{~kg} \mathrm{ha}^{-1}$. Productive area more than doubled when compared to the previous harvest, with a $48.5 \%$ production increase. The municipality of Campo Novo do Parecis, in the Cerrado/Savannah of Mato Grosso, grew $40 \%$ of all sunflower crop in the state. High sunflower production in the region is mainly due to industrialization and to the region's excellent edaphoclimatic conditions for its culture, such as altitude and well-defined dry season (Birck et al., 2017; Dalchiavon, Marchesini, Kimecz, Machado, \& Carvalho, 2018; Dalchiavon, Lorenzon, Perina, Oliveira, \& Santos, 2019; Dalchiavon, Marcondes, \& Carvalho, 2020).

The sunflower's agronomic features, such as tolerance to draught, heat and cold, nutritional and commercial value, plus the fact that agricultural systems have integrated crops for production improvement, favored the cultivation of the sunflower plant in the Cerrado of Mato Grosso as second harvest, with sowing between 
February and March, and providing crop succession and agricultural diversity (Kaya, Evci, Durak, Pekcan, \& Gücer, 2007; Porto et al., 2008; Dalchiavon et al., 2016a; Brighenti, 2018; Castro \& Leite, 2018).

Supply increase for sunflower crops has triggered further research, especially on obtaining and selecting new genotypes in the region (Kaya, Evci, Durak, Pekcan, \& Gücer, 2007; Porto et al., 2008; Branković et al., 2012). Selection has been provided in Brazil by the Network for Evaluation Assays on Sunflower Genotypes by Embrapa and performed by several public and private institutions in the country (Dalchiavon et al., 2016a; Castro \& Leite, 2018). Current assay determines the agronomic performance of sunflower hybrids in the Mid-Northern region of the state of Mato Grosso for the production of data for industrial segments. The information obtained in this study will be used to make a decision to launch cultivars.

\section{Material and Methods}

\subsection{Field Trial}

Current assay was performed on the experimental field of the Instituto Federal de Educação, Ciência e Tecnologia de Mato Grosso - Campus Campo Novo do Parecis, during the second summer harvest of the 2017-2018 agricultural year. The area is located at $13^{\circ} 40^{\prime} 37^{\prime \prime} \mathrm{S}$ and $57^{\circ} 47^{\prime} 30^{\prime \prime} \mathrm{W}$, altitude $564 \mathrm{~m}$. According to the Brazilian Soil Classification System, the soil of the experimental area is Red-Yellow Dystrophic Latosol (Typic Tropudox) (Dalchiavon, Montanari, Andreotti, Dallacort, \& Souza., 2015). According to Köppen's classification, local climate is Aw, or rather, tropical climate with well-defined dry season between May and September (Dallacort, Martins, Inoue, Freitas, \& Coletti, 2011) (Figure 1).

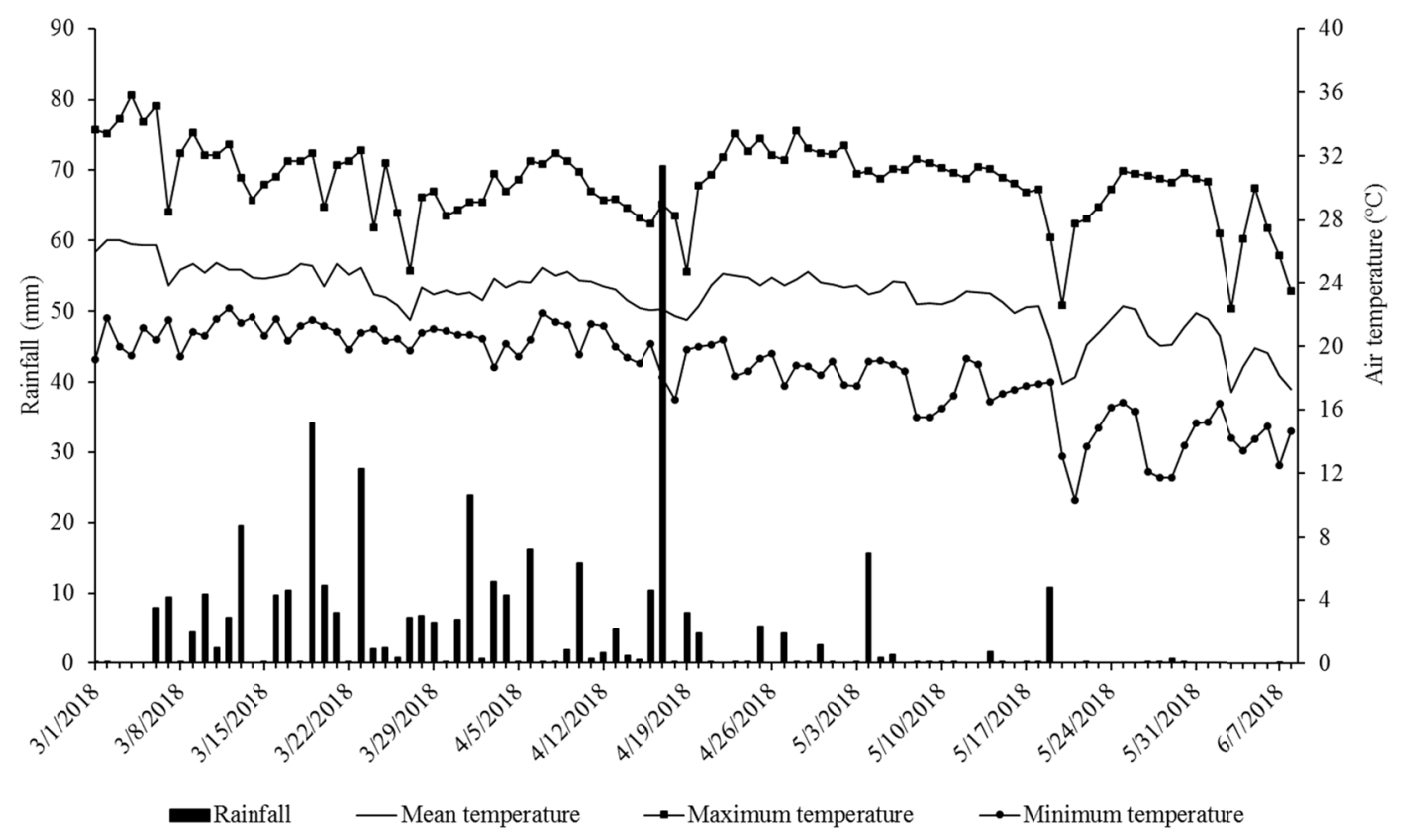

Figure 1. Rainfall and temperature averages in the experimental area from March to June 2018-Campo Novo do Parecis MT Brazil

The area was prepared after the soybean harvest (March 3, 2018) by spraying with glyphosate $\left(648 \mathrm{~g}\right.$ i.a. $\left.\mathrm{L}^{-1}\right)$ at $1.5 \mathrm{~L} \mathrm{ha}^{-1}$. Seeding fertilization followed with trailer sower at doses $20,84,40$ and $2 \mathrm{~kg} \mathrm{ha}^{-1}$ of $\mathrm{N}_{1} \mathrm{P}_{2} \mathrm{O}_{5}, \mathrm{~K}_{2} \mathrm{O}$ and $\mathrm{B}$, respectively. At stage V6, cover fertilization was undertaken with $14 \mathrm{~kg} \mathrm{ha}^{-1} \mathrm{~N}$ (urea), $20 \mathrm{~kg} \mathrm{ha}^{-1} \mathrm{~K}_{2} \mathrm{O}$ (potassium chloride) and $0.5 \mathrm{~kg} \mathrm{ha}^{-1} \mathrm{~B}$ (boric acid) to comply with crop requirements based on soil analysis.

Seeds were treated with insecticide Fipronil $250 \mathrm{~g} \mathrm{~L}^{-1}$ (pyrazole) and fungicides pyraclostrobin $25 \mathrm{~g} \mathrm{~L}^{-1}$ (strobirulin) + methyl thiophanate $225 \mathrm{~g} \mathrm{~L}^{-1}$ (benzimidazoles), $200 \mathrm{~mL}$ p.c./100 kg seeds. Two seeds per site were sown manually on March 4, 2018, and emerged six days after seeding. Thinning was performed seven days after emergence (DAE), with a final population of 45,000 plants per hectare, with 2.025 seeds per meter.

Weeds were controlled manually at 14 and 30 DAE. Pest control comprised thiametoxan + lambda cyalotrine $(14.1 \%+10.6 \%$ i.a. $)$ at $250 \mathrm{~mL} \mathrm{ha}^{-1}$, immediately after the emergence of plants and at $30 \mathrm{DAE}$ for the control of 
Diabrotica speciosa; at 37 DAE for the control of Spodoptera frugiperda and at 70 DAE for the control of Chlosyne lacinia saundersii. Three alternate applications of azoxystrobin (strobilurin $200 \mathrm{~g} \mathrm{~L}^{-1}$ i.a.) + difenoconazole (triazole $125 \mathrm{~g} \mathrm{~L}^{-1}$ i.a.) at $0.3 \mathrm{~L} \mathrm{ha}^{-1}$, and difenoconazole (triazole $250 \mathrm{~g} \mathrm{~L}^{-1}$ i.a.) at $0.35 \mathrm{~L} \mathrm{ha}^{-1}$, at 30, 45 and $68 \mathrm{DAE}$, were performed for the prevention of diseases, especially Alternaria spp. spots.

The head harvest was cut manually after R9 (physiological maturing) on June 06,2018 , followed by weighing of head, manual trailing, weighing of achenes and correction of moisture content of achenes (seed) to $11 \%$ (humid base).

\subsection{Traits}

Evaluated traits comprised days for initial florescence (IFD), with 50\% of plants at stage R4 and stage R5.5 (full florescence), plant height ( $\mathrm{PH})$, evaluated for ten plants per plot, from the soil to the insertion of the head; stalk diameter (SD) at $5 \mathrm{~cm}$ from the soil, and green (GM) and dry mass (DM) (stalk, leaf + petiole and head) in five plants per plot, continually harvested on the fourth row, extrapolating the value to the plant population per hectare.

The following were determined at stage R9 (physiological maturity): days for physiological maturity (DPM), mean diameter of the head (DC), mass of head and achenes per head (MA), both necessary to obtain achene:head ratio (RA), mass of one thousand achenes (MT), number of achenes per head (NA) and productivity of achenes (PA). Oil rate (OR), predicted by spectroscopy (Grunvald et al., 2014) and oil productivity (OP), calculated by the product of achene oil rate (\%) and achene productivity $\left(\mathrm{kg} \mathrm{ha}^{-1}\right) / 100$, were calculated.

\subsection{Design and Statistical Analysis}

Experimental design comprised randomized blocks with four replications and eight treatments with genotypes SYN 045, MULTISSOL, BRS 323, BRS G52, BRS G58, BRS G59, BRS G60 and BRS G61, developed through sunflower genetic improvement programs by different agencies. With the exception of MULTISSOL, a population of open pollenization, genotypes were simple hybrids. Experimental unit consisted of five $6 \mathrm{~m}$ rows, with a space of $0.45 \mathrm{~m}$. Side rows and $0.5 \mathrm{~m}$ from the edges formed the borders.

When data complied with homogeneity and constant variance, they underwent analysis of variance and Scott-Knott test $(\mathrm{p}<0.05)$, with SISVAR 5.6.

\section{Results and Discussion}

Analysis of variance revealed significant differences for the variables under analysis, with the exception of the number of achenes per head (Table 1).

Table 1. Analysis of variance for productive variables of sunflower genotypes cultivated in second harvest-Campo Novo do Parecis MT Brazil, 2018

\begin{tabular}{llll}
\hline Variables $^{1}$ & $\mathrm{~F}^{2}$ & $\mathrm{CV}(\%)^{3}$ & $\mathrm{GM}^{4}$ \\
\hline DIF (days) & $129.2^{* *}$ & 1.0 & 50.6 \\
DPM (days) & $30^{* *}$ & 1.1 & 91.5 \\
PH $(\mathrm{cm})$ & $22.9^{* *}$ & 5.8 & 150.3 \\
$\mathrm{GM}\left(\mathrm{t} \mathrm{ha}^{-1}\right)$ & $3.2^{*}$ & 17.1 & 35.8 \\
DM $\left(\mathrm{t} \mathrm{ha}^{-1}\right)$ & $14.3^{* *}$ & 13.5 & 3.3 \\
MTA $(\mathrm{g})$ & $30.2^{* *}$ & 6.5 & 62.6 \\
MAC $(\mathrm{g})$ & $10.1^{* *}$ & 13.7 & 62.3 \\
ACR & $4.1^{* *}$ & 14.9 & 0.54 \\
NAC & 1.5 & 10.4 & 1022 \\
PA $\left(\mathrm{kg} \mathrm{ha}^{-1}\right)$ & $30.5^{* *}$ & 9.1 & 2412.0 \\
OR $(\%)$ & $4.2^{*}$ & 4.0 & 42.1 \\
OP $\left(\mathrm{kg} \mathrm{ha}^{-1}\right)$ & $28.5^{* *}$ & 9.5 & 1011.5 \\
\hline
\end{tabular}

Note. ${ }^{1} \overline{\mathrm{DIF}}=$ days after initial florescence; DPM = days after physiological maturity; $\mathrm{PH}=$ plant height; $\mathrm{GM}=$ green mass; DM = dry mass, MTA = mass of one thousand archenes; MAC = mass of archenes per head; ACR = archene:head ratio; $\mathrm{NAC}=$ number of archenes per head; $\mathrm{PA}=$ productivity of archenes; $\mathrm{OR}=$ oil rate; $\mathrm{OP}=$ oil productivity; ${ }^{2} * *,{ }^{*}$ significant at 1 and $5 \%$, respectively; ${ }^{3} \mathrm{CV}=$ coefficient of variation; ${ }^{4} \mathrm{GM}=$ general means. 
Genotype SYN 045 revealed the tallest plant (PH), with $183.2 \mathrm{~cm}$ (Table 2). The other genotypes demonstrated PH between $128.3 \mathrm{~cm}$ (BRS G52) and $168.6 \mathrm{~cm}$ (MULTISSOL), with no significant statistical difference. According to Dalchiavon et al. (2016a) and Dalchiavon, Malacarne, and Carvalho (2016b), small-sized plants facilitate crop treatment and tend to reduce lodging and breaks in adverse climate conditions. These authors reported plant heights similar to those in current assay for SYN 045 and BRS 323 cultivated in similar edaphoclimatic conditions, similar to those in current assay.

Table 2. Mean rates for plant height (PH), days for initial florescence (DIF), days for physiological maturity (DFM), green mass (GM) and dry mass (DM) of sunflower genotypes cultivated in second harvest-Campo Novo do Parecis MT Brazil, 2018

\begin{tabular}{llllll}
\hline Genotypes & PH $(\mathrm{cm})$ & DIF (dias) & DFM (dias) & GM $\left(\mathrm{t} \mathrm{ha}^{-1}\right)$ & DM $\left(\mathrm{t} \mathrm{ha}^{-1}\right)$ \\
\hline SYN 045 & $183.2 \mathrm{a}$ & $54 \mathrm{a}$ & $96 \mathrm{a}$ & $45.0 \mathrm{a}$ & $5.0 \mathrm{a}$ \\
BRS 323 & $167.9 \mathrm{~b}$ & $52 \mathrm{~b}$ & $93 \mathrm{~b}$ & $36.8 \mathrm{~b}$ & $3.9 \mathrm{~b}$ \\
MULTISSOL & $168.6 \mathrm{~b}$ & $55 \mathrm{a}$ & $95 \mathrm{a}$ & $33.3 \mathrm{~b}$ & $3.7 \mathrm{~b}$ \\
BRS G60 & $138.2 \mathrm{~b}$ & $48 \mathrm{c}$ & $89 \mathrm{c}$ & $33.7 \mathrm{~b}$ & $2.8 \mathrm{c}$ \\
BRS G61 & $154.7 \mathrm{~b}$ & $52 \mathrm{~b}$ & $92 \mathrm{~b}$ & $26.2 \mathrm{~b}$ & $3.1 \mathrm{c}$ \\
BRS G52 & $128.3 \mathrm{~b}$ & $48 \mathrm{c}$ & $89 \mathrm{c}$ & $36.7 \mathrm{~b}$ & $2.8 \mathrm{c}$ \\
BRS G58 & $129.6 \mathrm{~b}$ & $48 \mathrm{c}$ & $89 \mathrm{c}$ & $40.7 \mathrm{~b}$ & $2.8 \mathrm{c}$ \\
BRS G59 & $132.1 \mathrm{~b}$ & $48 \mathrm{c}$ & $89 \mathrm{c}$ & $34.4 \mathrm{~b}$ & $2.3 \mathrm{c}$ \\
\hline
\end{tabular}

The earliest genotypes bloomed after 48 days (BRS G52, BRS G58, BRS G59 and BRS G60), whereas the others bloomed after 52 days (BRS 323 and BRS G61); while others bloomed after 53 days (SYN 045 and MULTISSOL) after emergence (Table 2). Average temperatures of maximum, mean and minimum temperatures during the assay were $23.1,30.3$ and $18.5^{\circ} \mathrm{C}$, respectively, with accumulated rainfall at $416.8 \mathrm{~mm}$ (Figure 1), warranting the plants' normal development (Vear, 2016; Castro \& Leite, 2018).

According to Kaya, Evci, Durak, Pekcan, and Gücer (2007) and Santana, Souza, G. M. S. S. Santos, L. G. Santos, and Peixoto (2016), early florescence (IFD) is related to early physiological maturity (DPM), since harvest is anticipated and liabilities due to attacks by birds or pests at the cycle's end are avoided, even if earliness is also related to low achene productivity (Kaya, Evci, Durak, Pekcan, \& Gücer, 2007). In current assay, the genotypes had similar behavior for IFD and DPM. In fact, the earliest genotypes were BRS G52, BRS G58, BRS G59 and BRS G60, which reached physiological maturity 89 days after emergence (Table 2). On the other hand, the later SYN 045 amd MULTISSOL matured after 96 and 95 days after emergence, respectively. Genotype BRS 323 matured at the same period, as reported by Dalchiavon, Malacarne, and Carvalho (2016b). The precocity of the genotypes with influence on environmental conditions (Goyal et al., 2011) has the advantage of shorter exposure time of the crop on the field. This fact lessens occurrence of insects, diseases and water deficit and may facilitate management if curing practices are discarded. They may be solved by a correct selection of the cultivar (Dalchiavon et al., 2016a).

SYN 045 had the highest rates in green and dry mass, respectively with 45.0 and $5.0 \mathrm{t} \mathrm{ha}^{-1}$ (Table 2), whereas means of the other genotypes ranged between 26.2 and $40.7 \mathrm{tha}^{-1}$ for green mass and between 2.3 and $3.9 \mathrm{tha}^{-1}$ for dry mass. Besides SYN 045, the hybrids BRS 323 and MULTISSOL were highlighted for dry mass, a relevant feature in silage production. According to Saha et al. (2017), height of plant and stalk diameter may be relevant in the increase of dry mass, as reported in current assay. In fact, increase in fibers is essential for animal feed.

Achene mass per head for genotypes SYN 045, BRS 323 and MULTISSOL was the same. Their average was $78.4 \mathrm{~g}$ (Table 3), and exceeded by $48.8 \%$ the average of the genotypes with the lowest head mass (average 52.7 g). 
Table 3. Average rates for mass of achene per head (MAC), achene-head ratio (ACR), mass of one thousand achenes (MTA), productivity of achenes (PA), oil rate (OR) and oil productivity (OP) of sunflower genotypes in second harvest-Campo Novo do Parecis MT Brazil, 2018

\begin{tabular}{lllllll}
\hline Genotypes & MAC $(\mathrm{g})$ & ACR & MTA $(\mathrm{g})$ & PA $\left(\mathrm{kg} \mathrm{ha}^{-1}\right)$ & OR $(\%)$ & OP $\left(\mathrm{kg} \mathrm{ha}^{-1}\right)$ \\
\hline SYN 045 & $82.4 \mathrm{a}$ & $0.45 \mathrm{~b}$ & $76.9 \mathrm{a}$ & $3552.2 \mathrm{a}$ & $43.7 \mathrm{a}$ & $1550.7 \mathrm{a}$ \\
BRS 323 & $77.6 \mathrm{a}$ & $0.52 \mathrm{~b}$ & $76.2 \mathrm{a}$ & $2888.9 \mathrm{~b}$ & $41.4 \mathrm{a}$ & $1187.2 \mathrm{~b}$ \\
MULTISSOL & $75.3 \mathrm{a}$ & $0.47 \mathrm{~b}$ & $74.3 \mathrm{a}$ & $2850.1 \mathrm{~b}$ & $42.5 \mathrm{a}$ & $854.4 \mathrm{~d}$ \\
BRS G60 & $52.1 \mathrm{~b}$ & $0.64 \mathrm{a}$ & $51.8 \mathrm{c}$ & $2146.8 \mathrm{c}$ & $42.5 \mathrm{a}$ & $815.5 \mathrm{~d}$ \\
BRS G61 & $55.8 \mathrm{~b}$ & $0.44 \mathrm{~b}$ & $58.6 \mathrm{~b}$ & $2032.0 \mathrm{c}$ & $42.8 \mathrm{a}$ & $813.3 \mathrm{~d}$ \\
BRS G52 & $49.0 \mathrm{~b}$ & $0.62 \mathrm{a}$ & $56.7 \mathrm{~b}$ & $2010.7 \mathrm{c}$ & $42.3 \mathrm{a}$ & $907.4 \mathrm{~d}$ \\
BRS G58 & $55.2 \mathrm{~b}$ & $0.62 \mathrm{a}$ & $56.7 \mathrm{~b}$ & $1920.1 \mathrm{c}$ & $43.2 \mathrm{a}$ & $875.9 \mathrm{~d}$ \\
BRS G59 & $51.5 \mathrm{~b}$ & $0.58 \mathrm{a}$ & $49.4 \mathrm{c}$ & $1895.0 \mathrm{c}$ & $38.2 \mathrm{~b}$ & $1087.1 \mathrm{c}$ \\
\hline
\end{tabular}

BRS G60, BRS G52, BRS G58, and BRS G59 were the genotypes with the highest achene-head ratio, featuring rates between 0.58 and 0.64 (Table 3). On the other hand, genotypes SYN 045, BRS 323, MULTISSOL and BRS G61 had the lowest conversion rate in photosynthesis energy for the capitula in the achenes. According to Dalchiavon, Malacarne, and Carvalho (2016b), data on achene-head ratio is highly important. The higher the rate of the variable, the greater is the useful mass of the head. In other words, the greater is the plant's efficiency in directing its energy towards the production of achenes.

The mass of one thousand achenes oscillated between 49.4 (BRS G59) and $76.9 \mathrm{~g}$ (SYN 045). Genotypes BRS 323 and MULTISSOL had rates similar to SYN 045 (Table 3), over all the others. It should also be highlighted that SYN 045 showed higher rates than those reported by Dalchiavon, Malacarne, and Carvalho (2016b), Poletine et al. (2016) and Stasiak et al. (2018) in different regions of Brazil. According to Kaya, Evci, Durak, Pekcan, and Gücer (2007) and Dalchiavon, Malacarne, and Carvalho (2016b), the mass of one thousand achenes is the main component in sunflower production which, when associated with the number of achenes per head, has a direct relationship with productivity of achenes. Consequently, genotypes with the greatest masses of one thousand achenes have potentially superior productivity. This implies that, besides the genetic factor, environmental conditions and above all the correct management are basic factors towards success and productivity (Castro \& Leite, 2018).

Accumulated rainfall during the period (Figure 1) and disease prevention management were favorable to the good development of sunflower plants and low occurrence rate of Alternaria spp. (the region's main disease), which are basic conditions for average good productivity of achenes of the tested genotypes, with $2,412.0 \mathrm{~kg} \mathrm{ha}^{-1}$ (Table 1). Productivity was 53\% higher than Brazil's average for the same harvest $\left(1578 \mathrm{~kg} \mathrm{ha}^{-1}\right)(\mathrm{CONAB}$, 2018). It is a clear proof that the Mid-northern region of the state of Mato Grosso is favorable to sunflower crops in second harvest.

Genotype SYN 045 had the highest achene productivity rates $\left(3,552.2 \mathrm{~kg} \mathrm{ha}^{-1}\right)$, followed by BRS 323 and MULTISSOL (3,552.2 $\mathrm{kg} \mathrm{ha}^{-1}$ ) (Table 3). These genotypes had the greatest MM and MA. Similar to study by Dalchiavon et al. (2016a), it has been proved that big-sized plants had the greatest productivity rates in achenes, coupled to the fact that they had greatest cycle, as reported by Kaya, Evci, Durak, Pekcan, and Gücer (2007). Genotypes with the greatest productivity rates in achenes were also those with the lowest rates in achene-head ratio (Table 3), differing from Dalchiavon, Malacarne, and Carvalho (2016b).

With the exception of MULTISSOL (38.2\%), all genotypes provided statistically similar oil rates, above $40 \%$, or rather, the limit established by some industries which predict depreciation or bonus of the product when oil rate is respectively lower or above the limit (Porto et al., 2008). A high bonus reveals the importance of cultivating genotypes with high oil yield when compared to grain yield. Based on oil rates in Table 3, the hybrid SYN 045 revealed the highest oil yield $\left(1,550.7 \mathrm{~kg} \mathrm{ha}^{-1}\right)$, followed by BRS $323\left(1,187.2 \mathrm{~kg} \mathrm{ha}^{-1}\right)$.

Hybrid SYN 045 had the highest yields in grain and oil in Campo Novo do Parecis (MT), Brazil's main producer region in sunflower. Hybrid BRS 323 had good productivity in grains and oil, featuring small-size and a slightly lower cycle than that of SYN 045 . The open pollenization population MULTISSOL provided grain yield similar to BRS 323 , with oil rate lower than $40 \%$. The above data are relevant for the production and industry sectors to select genotypes with the best agronomic traits when cultivated in the mentioned region. 


\section{Conclusions}

Hybrids SYN 045 and BRS 323 proved to have a good grain and oil productivity in the Mid-Northern region of the state of Mato Grosso, the main producing region of sunflowers in Brazil.

\section{Acknowledgements}

The authors would like to thank the Research Group in Phytotechny (GPF) of the Federal Institute of Education, Science and Technology of Mato Grosso (IFMT)-Campus Campo Novo do Parecis and the Mato Grosso State Research Support Foundation (Fapemat), for its help and funding.

\section{References}

Birck, M., Dalchiavon, F. C., Stasiak, D., Iocca, A. F. S., Hiolanda, R., \& Carvalho, C. G. P. de. (2017). Performance of sunflower cultivars at different seeding periods in central Brazil. Ciência e Agrotecnologia, 41(1), 42-51. https://doi.org/10.1590/1413-70542017411021216

Branković, G. R., Balalić, I. M., Zorić, M. Z., Miklič, V. J., Jocić, S. B., Momirović, \& G. G. Š. (2012). Characterization of sunflower testing environments in Serbia. Turkish Journal of Agriculture and Forestry, 36(3), 275-283. https://doi.org/10.3906/tar-1106-45

Brighenti, A. M. (2018). Sulfentrazone for volunteer soybean control and selectivity in sunflower crop. Interciencia, 43(4), 256-260.

Castro, C., \& Leite, R. M. V. B. C. (2018). Main aspects of sunflower production in Brazil. Oilseeds \& Fats Crops and Lipids, 25(1), 2-11. https://doi.org/10.1051/ocl/2017056

CONAB (Companhia Nacional de Abastecimento). (2018). Acompanhamento da safra brasileira-Grãos: Safra (2017/2018) (Décimo primeiro Levantamento, V. Mensal, August, 2018). Retrieved August 20, 2018, from http://www.CONAB.gov.br

Dalchiavon, F. C., Carvalho, C. G. P. de, Amabile, R. F., Godinho, V. P. C. de, Ramos, N. P., \& Anselmo, J. L. (2016a). Características agronômicas e suas correlações em híbridos de girassol adaptados à segunda safra. Pesquisa Agropecuária Brasileira, 51(11), 1806-1812. https://doi.org/10.1590/s0100-204x2016001100002

Dalchiavon, F. C., Lorenzon, L. A., Perina, R. de A., Oliveira, R. A. de, \& Santos, J. A. dos. (2019). Economic Opportunity for Investment in Soybean and Sunflower Crop System in Mato Grosso, Brazil. Journal of Experimental Agriculture International, 29(1), 1-12. https://doi.org/10.9734/JEAI/2019/45695

Dalchiavon, F. C., Malacarne, B. J., \& Carvalho, C. G. P. de. (2016b). Características agronômicas de genótipos de girassol (Helianthus annuus L.) em segunda safra no Chapadão do Parecis: MT. Revista de Ciências Agrárias, 39(1), 178-186. http://dx.doi.org/10.19084/RCA15049

Dalchiavon, F. C., Marchesini, M. J., Kimecz, A. M., Machado, D. H., \& Carvalho, C. G.P. de. (2018). Performance of sunflower hybrids cultivated in different sowing seasons in Mato Grosso, Brazil. Journal of Experimental Agriculture International, 28(1), 1-8. https://doi.org/10.9734/JEAI/2018/45302

Dalchiavon, F. C., Marcondes, D. A. P., \& Carvalho, C. G. P. de. (2020). Seed Distribution Mechanisms and Sowing Speed on Plantability and Agronomic Characteristics of Sunflower. Journal of Agricultural Science, 12(4), 119-127. https://doi.org/10.5539/jas.v12n4p119

Dalchiavon, F. C., Montanari, R., Andreotti, M., Dallacort, R., \& Souza, M. F. P. (2015). Relationship between sunflower productivity and soil's chemical properties by geo-statistical techniques. African Journal of Agricultural Research, 10(35), 3525-3532. https://doi.org/10.5897/AJAR2014.9472

Dallacort, R., Martins, J. A., Inoue, M. H., Freitas, P. S. L., \& Coletti, A. J. (2011). Distribuição das chuvas no município de Tangará da Serra, médio norte do Estado de Mato Grosso, Brasil. Acta Scientiarum Agronomy, 33(2), 193-200. https://doi.org/10.4025/actasciagron.v33i2.5838

Goyal, A., Beres, B. L., Randhawa, H. S., Navabi, A., Salmon, D. F., \& Eudes, F. (2011). Yield stability analysis of broadly adaptive triticale germplasm in southern and central Alberta, Canada, for industrial end-use suitability. Canadian Journal of Plant Science, 91(1), 125-135. https://doi.org/10.4141/cjps10063

Grunvald, A. K., Carvalho, C. P. G. de, Leite, R. S., Mandarino, J. M. G., Andrade, C. A. de B., \& Scapim, C. A. (2014). Predicting the oil contents in sunflower genotype seeds using near-infrared reflectance (NIR) spectroscopy. Acta Scientiarum Agronomy, 36(2), 233-237. https://doi.org/10.4025/actasciagron.v36i2. 17677 
Kaya, Y., Evci, G., Durak, S., Pekcan, V., \& Gücer, T. (2007). Determining the Relationships between Yield and Yield Attributes in Sunflower. Turkish Journal of Agriculture and Forestry, 31(4), 237-244.

Kösoğlu, K., Yumuk, S., Aydin, Y., Evci, G., \& Uncuoğlu, A. A. (2017). Use of SNP markers by KASP assay for MAS studies in sunflower against Plasmopara halstedii. Turkish Journal of Agriculture and Forestry, 41(6), 480-489. https://doi.org/10.3906/tar-1707-53

Poletine, J. P., Borázio, R. F., Barelli, M. A. A., Severino, J. Jr., Aufusto, J., \& Silva, G. C. M. (2016). Quantificação da divergência genética entre híbridos superiores de girassol. Journal of Agronomic Sciences, $5(1), 29-45$.

Porto, W. S., Carvalho, C. G. P. de, Pinto, R. J. B., Oliveira, M. F., \& Oliveira, A. C. B. (2008). Evaluation of sunflower cultivar for central Brazil. Scientia Agricola, 65(2), 139-144. https://doi.org/10.1590/S0103-9016 2008000200005

Saha, U., Endale, D., Tillman, P. G., Johnson, W. C., Gaskin, J., Sonon, L., .. Yang, Y. (2017). Analysis of various quality attributes of sunflower and soybean plants by near infrared reflectance spectroscopy: development and validation calibration models. American Journal of Analytical Chemistry, 8(7), 462-492. https://doi.org/10.4236/ajac.2017.87035

Santana, M., Souza, V. N., Santos, G. M. S. S., Santos, L. G., \& Peixoto, L. S. (2016). Desempenho agronômico de genótipos de girassol no sudoeste baiano para produção de biocombustíveis. Enciclopédia Biosfera, 13(23), 422-431.https://doi.org/10.18677/Enciclopedia_Biosfera_2016_037

Stasiak, D., Dalchiavon, F. C., Birck, M., Hiolanda, R., Iocca, A. F. S., Coletti, A. J., \& Carvalho, C. G. P. de. (2018). Agronomic characteristics of sunflower genotypes according to plant population. Revista de Ciências Agrárias, 41(1), 4-13. https://doi.org/10.19084/RCA17152

Vear, F. (2016). Changes in sunflower breeding over the last fifty years. Oilseeds \& Fats Crops and Lipids, 23(2), 1-8. https://doi.org/10.1051/ocl/2016006

\section{Copyrights}

Copyright for this article is retained by the author(s), with first publication rights granted to the journal.

This is an open-access article distributed under the terms and conditions of the Creative Commons Attribution license (http://creativecommons.org/licenses/by/4.0/). 